Supplemental Information for:

\title{
Lidar reveals uniform Alpine Fault offsets and bimodal plate boundary rupture behaviour, New Zealand
}

By

\author{
Gregory P. De Pascale ${ }^{*+}$, Mark C. Quigley, and Tim R.H. Davies \\ Department of Geological Sciences, University of Canterbury, Christchurch, 8140, \\ New Zealand \\ +Currently at Fugro Geotechnical (NZ), Middleton, Christchurch, 8024, New \\ Zealand \\ *E-mail: snowyknight@gmail.com
}

This supplemental information file includes extra information regarding our methods for mapping, field photographs, additional tables and mapping.

\section{METHODS}

A number of methods were used in this investigation to characterize slip along the Alpine Fault and to determine the relationship between recent slip along the fault with estimates of earthquake timing. These methods were direct outcomes from fieldwork under taken during De Pascale PhD thesis research (De Pascale, 2014). First we accessed all previous documentation of dextral slip in the literature and compiled a database of slip distribution (Fig. 3.2). It is important to note that prior to this work there were only 7 sites that document short $(<30 \mathrm{~m})$ of dextral slip along the entire onshore fault, which demonstrates how challenging it is to collect data in a temperate rainforest (Berryman, 1975; Sutherland and Norris, 1995; Wells et al., 1999; Langridge et al., 2010; Berryman et al., 2012a and b). At locations where dextral slip was not explicitly noted in the text but with offsets noted on mapping (e.g. 
Toaroha River; Wells et al., 1999), whenever there were two strike-slip fault strands that offset the same landform (e.g. one channel margin), the sum of the two dextral offsets along both of the strands would form the cumulative or single offset at this site (after Sieh, 1978). Based on the literature review, there was $\sim 200 \mathrm{~km}$ of the fault between the Haast and the Toaroha Rivers without a single short dextral slip measurement reported.

A 1-km wide, airborne light detection and ranging (lidar) survey and associated orthophoto datasets were collected and processed for $34 \mathrm{~km}$ along the central Alpine Fault (Fig. 3.3), in July 2010 by New Zealand Aerial Mapping (NZAM). NZAM was responsible for all of the lidar data collection, processing, and field checking. A full description of the data collection and subsequent analysis is summarized by Langridge et al. (2013). The lidar sensor positioning and orientation (POS) was determined using the collected GPS/IMU datasets and Applanix POSPac software. This work was all undertaken in NZGD2000 coordinate system using the data collected at the geodetic reference mark for the DGPS processing. The POS data were combined with the lidar range files and used to generate lidar point clouds in New Zealand Transverse Mercator (NZTM) map projection but NZGD2000 ellipsoidal heights. This process was undertaken using Optech DASHMap lidar processing software. The point cloud data were then classified into ground, first and intermediate returns using automated routines tailored to the project landcover and terrain. At the outset of the project a decision was made to investigate the ground points on a strip-by-strip basis so the impact of point density on modelling accuracy could be studied. However, it was found that the individual strips had an inadequate number of points on the ground for the algorithms to work successfully. So, the entire dataset was processed through the automated routine. These, and subsequent steps 
were undertaken using TerraSolid lidar processing software modules TerraScan, TerraPhoto and TerraModeler. An average point spacing of $1.2 \mathrm{~m} /$ point allowed for the generation of the $2 \mathrm{~m}$ DEM and the data was checked for completeness of coverage. The relative fit of data in the overlap between strips was also checked. Comprehensive manual editing of the lidar point cloud data was undertaken to increase the quality of the automatically classified ground point dataset. This editing involved visually checking over the data and changing the classification of points into and out of the ground point dataset.

A combination of lidar and field mapping was used to detect and measure short offsets along the central Alpine Fault. The lidar point cloud data allowed the generation of a $2 \mathrm{~m}$ digital elevation model (DEM) that was imported into ArcGIS where hillshade, slopeshade, and topographic maps were used to delineate the traces of the Alpine Fault and measure displaced geomorphic features ( $<30$ m; Figs. 1-4), including identification linear valleys, sag ponds, thalwegs of small channels, channel margins, and wind gaps that helped demarcate Alpine Fault rupture traces. The abundance of rainfall, and dynamic nature of the landscape support the assumption that most fluvial features form between major earthquakes and are then offset by the next event, giving a clear record of progressive earthquakes (e.g. Wallace 1968; Grant Ludwig et al., 2010). Importantly, with the high-precipitation rates and presumed high coseismic uplift along the fault (see De Pascale, 2014), it is very likely that the combined coseismic uplift and post-seismic aggradation would facilitate the abandonment and preservation of prior offsets. We identified offset faultperpendicular features at seven sites along the fault (Fig. 1), projected them into the fault using a variety of angles reflecting uncertainties and by using fault parallel profiles (after Sieh, 1978; McGill and Sieh, 1991; Zielke et al., 2010; Salisbury et al., 
2012) and measured these offsets including estimated uncertainties in the lidar. The offset values measured in the Alpine Fault lidar were then tested by backslipping (after Frankel et al., 1997; Zielke et al., 2010) the topography based on the mapping in conjunction with the lidar data.

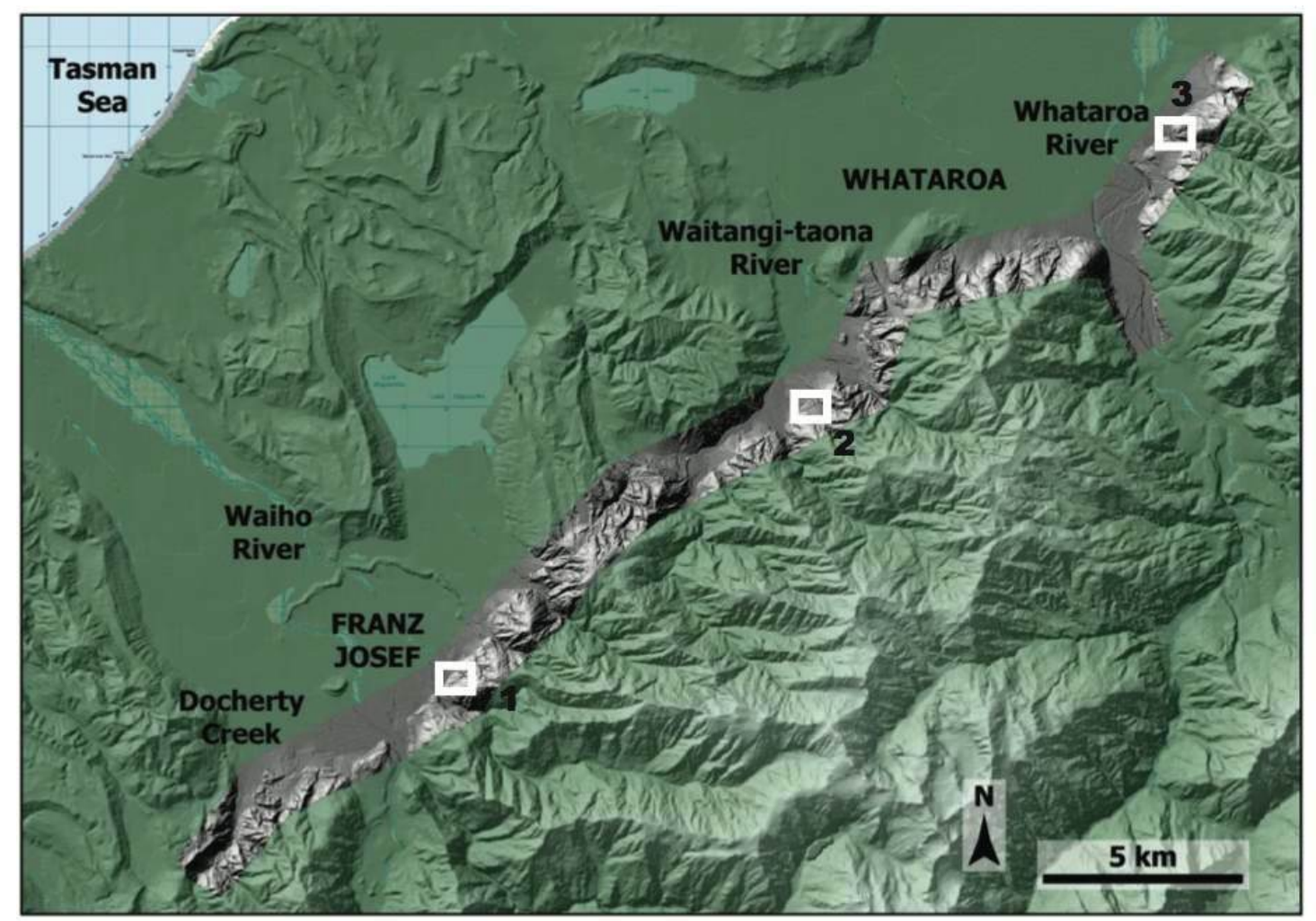

Figure DR1: Lidar (light detection and ranging) strip map location in Westland, New Zealand and context at the Western Southern Alps and important regional locations shown such as the locations of Franz Josef, the Waitangi-taona River, and the Whataroa River. White boxes outline short offset field locations; 1) Tartare Creek, 2) south of Gaunt Creek sites (including the windgap site), and 3) the McCulloughs Creek sites. Grayscale hillshade derived from $2 \mathrm{~m}$ lidar digital elevation model (DEM) overlain on hillshade from 25 m LINZ DEM data in green shades.

After addressing offsets along-strike of the fault, we then compiled the paleoseismic record for along the Alpine Fault for the past $1.1 \mathrm{ka}$ from all peerreviewed sources (Fig. 1 - main De Pascale et al., 2014 paper; Table 3). For this, we included all of the reported ages for events including their reported uncertainties.

These data were mapped both spatially and temporally to compare the differences and 
similarities between locations and timing of on- and off- fault paleoseismic data (Fig. 1 main paper).

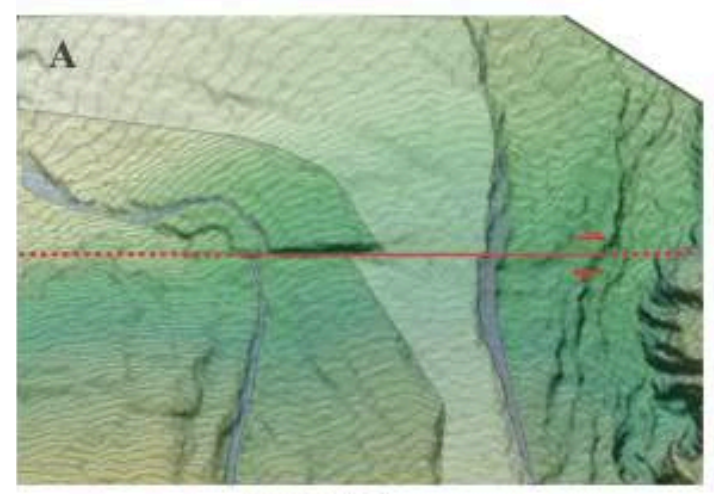

2010 lidar

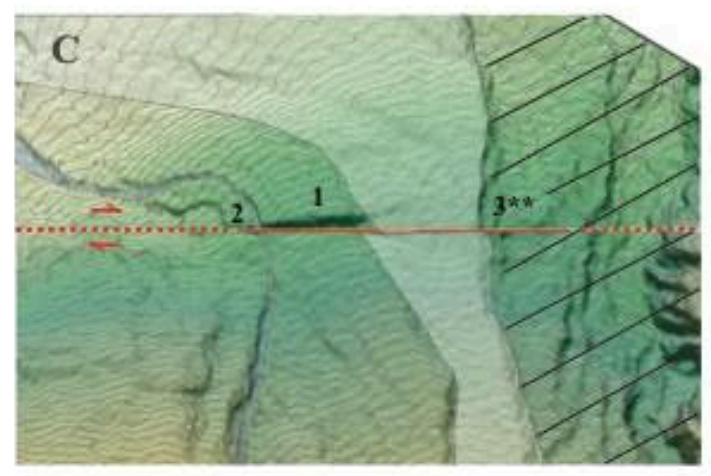

Pre-penultimate $(13.8 \pm 1.8 \mathrm{~m})$

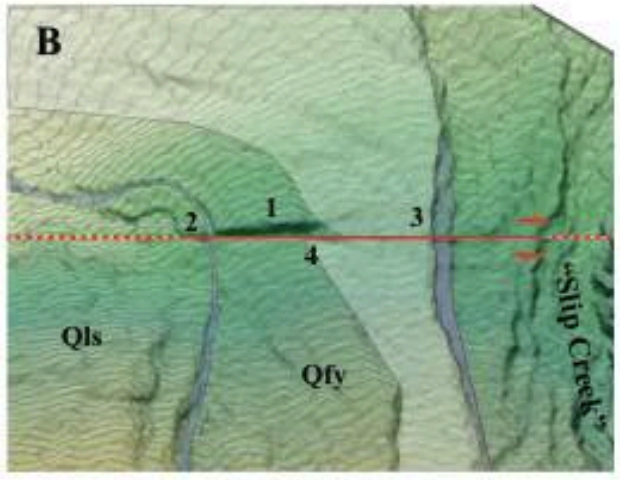

Pre-1717 $(7.5 \pm 1 \mathrm{~m})$

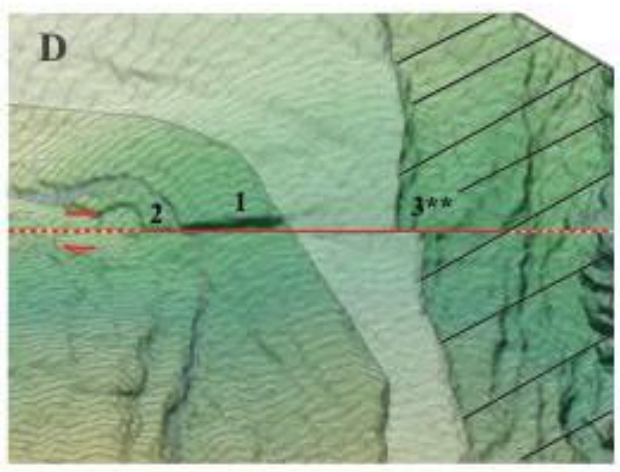

Pre-3rd event $(22 \mathrm{~m} \pm 2.7 \mathrm{~m})$

Figure DR2: Lidar hillshade maps of sites south of Gaunt Creek (wind gap), with back-slipping to restore landforms to pre-earthquake offsets for the past three events, (A) Post-1717 earthquake topography (2010 lidar topography), (B) the topography immediately prior to the MRE with $7.5 \pm 1 \mathrm{~m}$ dextral back-slip at the channel margin (3), (C) prior to the penultimate event with $13.75 \mathrm{~m} \pm 1.8 \mathrm{~m}$ dextral back-slip at the wind gap (2), (D) prior to the third oldest event with $22 \mathrm{~m} \pm 2.7 \mathrm{~m}$ of slip at the northeastern end of the shutter ridge (1). Note that the channel margins $(3 * *)$ are crossed to show that they likely formed after the penultimate event based on the backslipped results in (C) and (D). (4) is the location of a sag pond at the base of the shutter ridge that should be targeted for dating. 

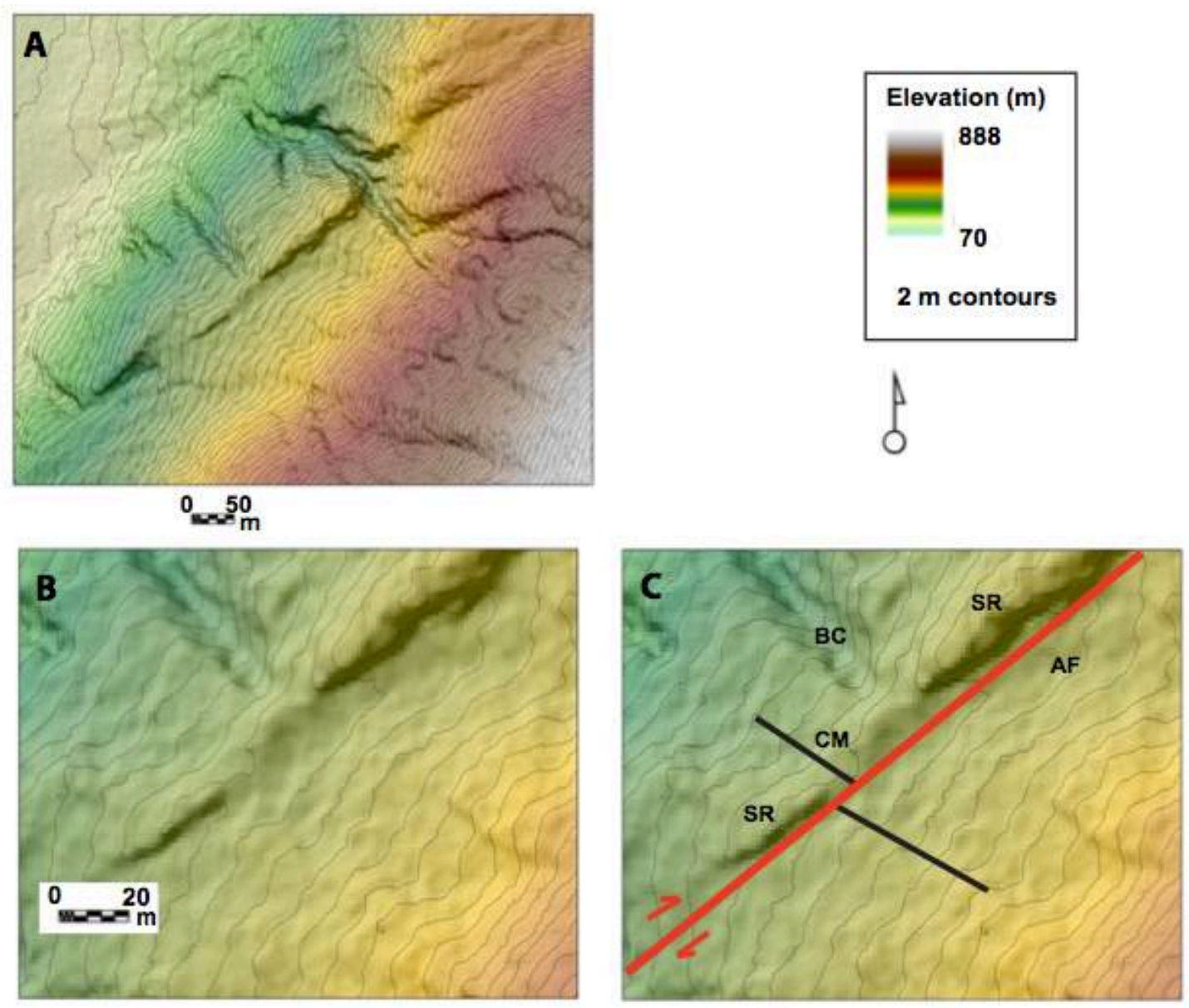

Figure DR3: Lidar site maps from the Tartare Creek site. A) Shows the site with 5 $\mathrm{m}$ contours, B) Shows the slip site uninterpreted with $2 \mathrm{~m}$ contours, and C) shows the interpreted data with the slip location of an offset channel margin. AF is the Alpine fault, BC is a beheaded channel, CM is the offset channel margin, and SR is a shutter ridge. 


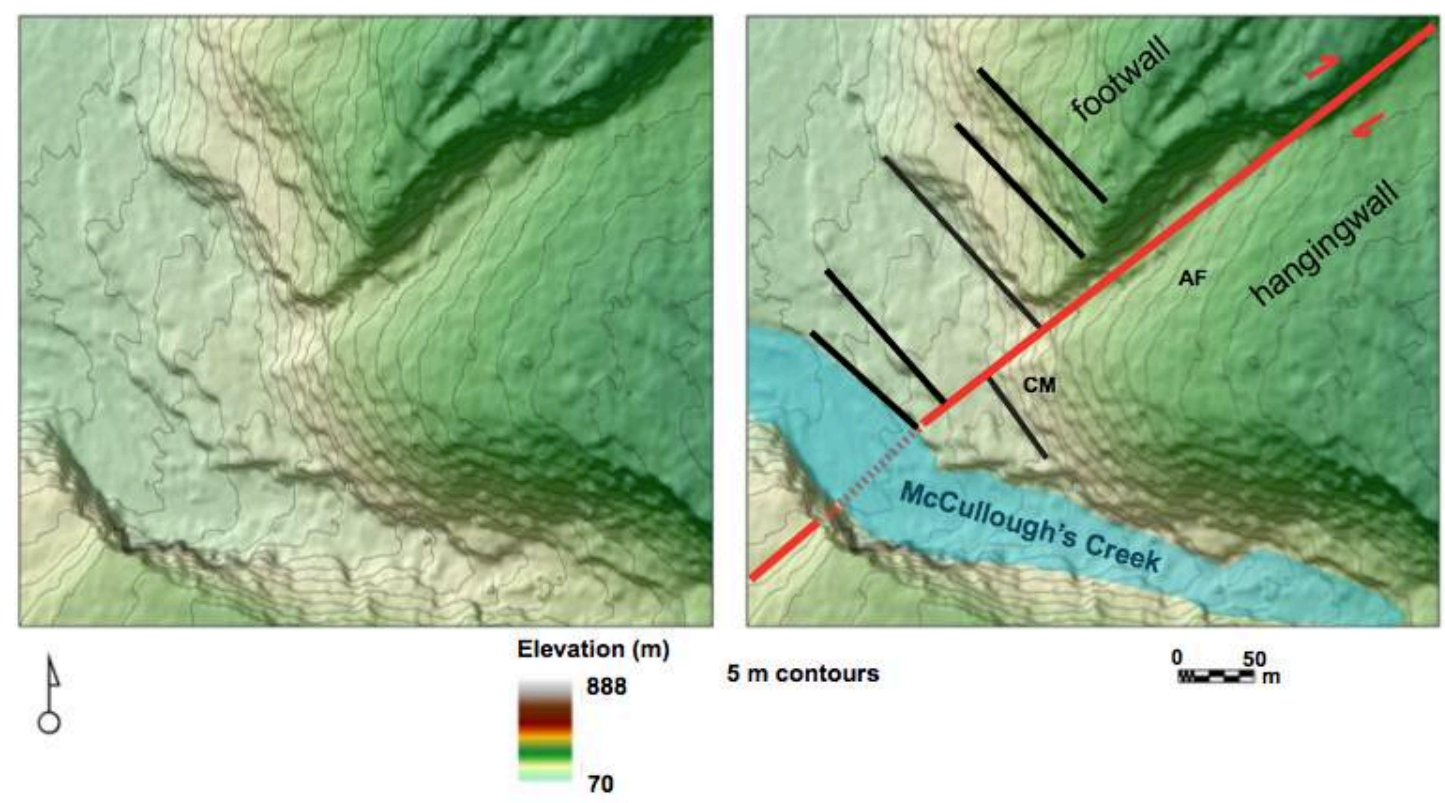

Figure DR4: Lidar site maps from the McCulloughs Creek area showing the uninterpreted site map on left and the interpreted map on the right with $5 \mathrm{~m}$ contours. AF stands for the Alpine Fault, and CM is for an offset channel margin. McCulloughs Creek's active creek bed is mapped in blue. Note the clear diachronous tread abandonment on the footwall (as shown in black with the number of terrace risers), with ages that systematically young from the upper riser (furthest away from the active channel) as first described by Cowgill (2007).

Through analysis of these maps, we recognized that preservation of dextral slip only seemed possible proximal to active, medium-sized creeks. Sites close to these creeks tended to have the last few dextral displacements preserved in the landscape. Because of the combination of steep slopes and high precipitation along the Alpine Fault (mean annual rainfall for the lidar swath area is ca. 3.8-4.8 $\mathrm{m}$ while in the drainage basins along the Southern Alps rangefront average 5-15 m annually; see http://www.niwa.co.nz; Griffiths and McSaveney, 1983), preservation of smalldistance $(<30 \mathrm{~m})$ dextrally-displaced features is uncommon. We found that by mapping active channels and recent floodplains, which are relatively easy to identify based on lack of vegetation cover and both areas where the main trace of the fault is obscured, we were able to map areas that would not have recent slip recorded at the surface. Importantly, sites immediately adjacent to these modern flood terraces, 
creeks, and river channels tend to be good locations for the preservation of slip records (Fig. 5) and these tended to be sites that would yield short displacements.

These were the sites we visited in the field and are discussed in the next section of this supplemental data.

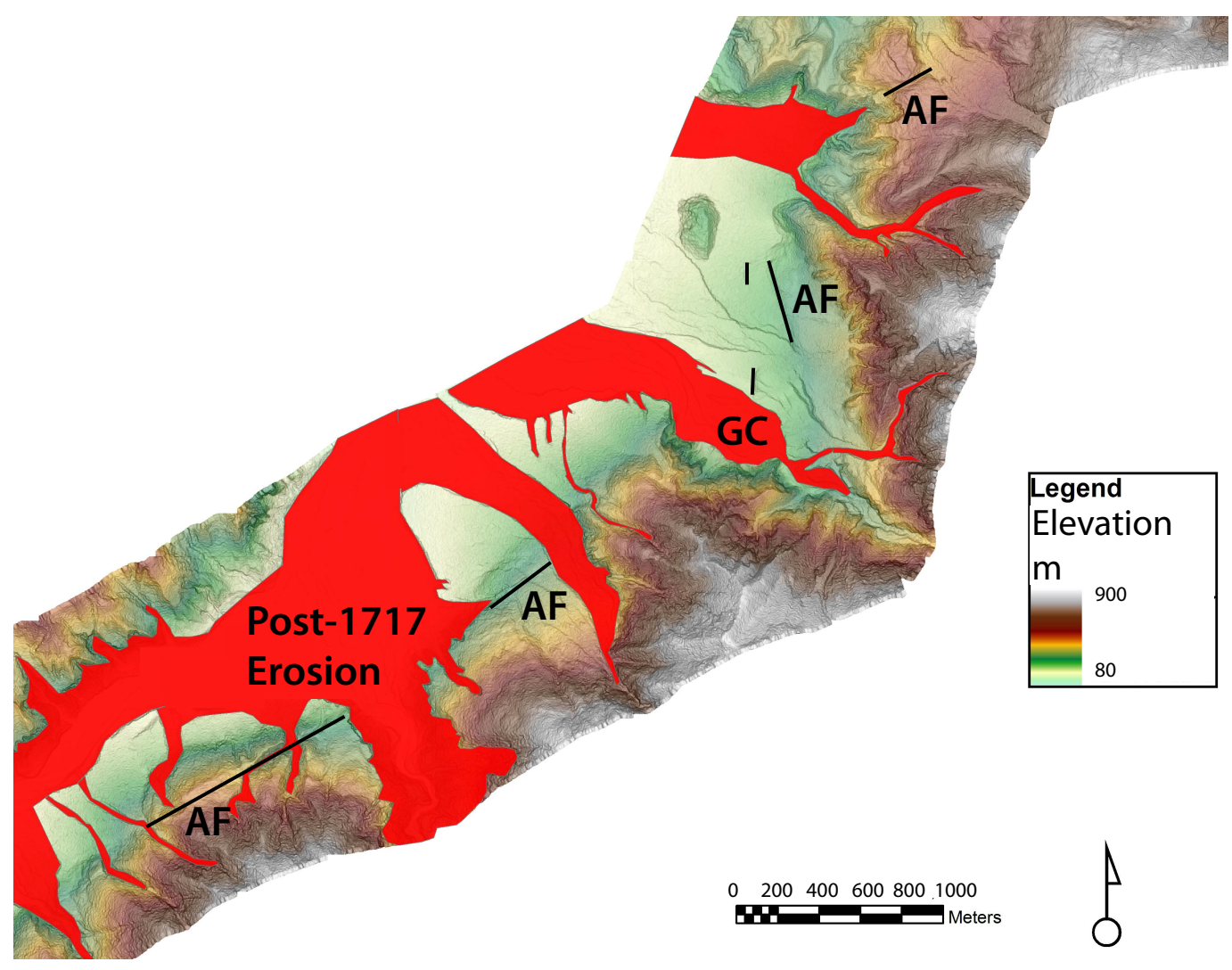

Figure DR5: Map showing an example from south of Gaunt Creek, near the wind gap slip sites, with recent (post-1717 earthquake) erosion and deposition mapped in red. Areas in red will not have any slip or other paleoseismic records at the surface due modern erosion and/or deposition at the site. Fault traces shown in black. Aerial view of a few of these sites can be seen in Figure 10.

With a $2 \mathrm{~m}$ DEM there are limitations on the resolution and precision of lidar measurements, therefore uncertainties from these measurements can be no less than plus or minus $2 \mathrm{~m}$. Each offset was assigned a qualifier of high, moderate, low, or poor quality (after Sieh, 1978), based on ease of matching across the fault and quality of offset fit to rate quality of offset features. With the lidar data, we took a preferred value with maximum and minimum values noted in order to obtain uncertainties at 
each slip site in conjunction with back-slipping of the data for best fit of offsets (Table 1; Fig. 1). The largest difference between the preferred value and accepted minimum or maximum value was therefore used to assign the uncertainty to the ideal displacement measurement (e.g. Zielke et al., 2010; Salisbury et al., 2012). These values were then tabulated (Table 3.3).

Field validation of lidar mapping, along with field measurements of fault displacements along the Alpine Fault, are extremely difficult. Not only is most of the rangefront along the Alpine Fault a wilderness (Westland National Park) with dense rainforest, trail-less, and often without road access, there are also a number of major rivers and creeks that must be crossed on foot to access field sites. Each of the sites mapped in the lidar was however located in the field and re-measured. Because of the extremely rugged nature of the terrain and thick temperate rainforest vegetation, typically we noted coordinates for sites of interest in the lidar and imported these into handheld Garmin GPS 60x systems to assist with locating these sites on the ground. We found that no other GPS system, including a differential GPS system, was able to hold a signal with the GPS satellites under the dense rainforest canopy and with the high mask angles and steep slopes along the rangefront of the Southern Alps. Existing creek channels were often used to expedite access through the dense rainforest and using a handheld GPS was invaluable for helping to locate the sites of interest from the lidar as sometimes we were within tens of meters of an offset location (e.g. Tartare Creek), but the dense rainforest obscured views (e.g. Fig. 6). Once at the sites on the ground, dense vegetation was not always an issue as some locations were relatively open at ground level (e.g. South of Gaunt Creek; Fig. 7). After finding offset sites in the field using printed lidar maps combined with a pre-waypoint loaded GPS, we used standard geomorphic methods (tape measure and compass) to measure displaced 
features in the field in conjunction with other researchers for objective measurements.

A minimum of three slip measurements was collected for each offset feature in the

field and we accounted for the projection angle of the offset features as in the lidar

mapping. As with the lidar data, the difference between the preferred value and

minimum and maximum values was the basis for the uncertainty values (after Zielke

et al., 2010; Salisbury et al., 2012). All of the field sites were visited on more than one

occasion.

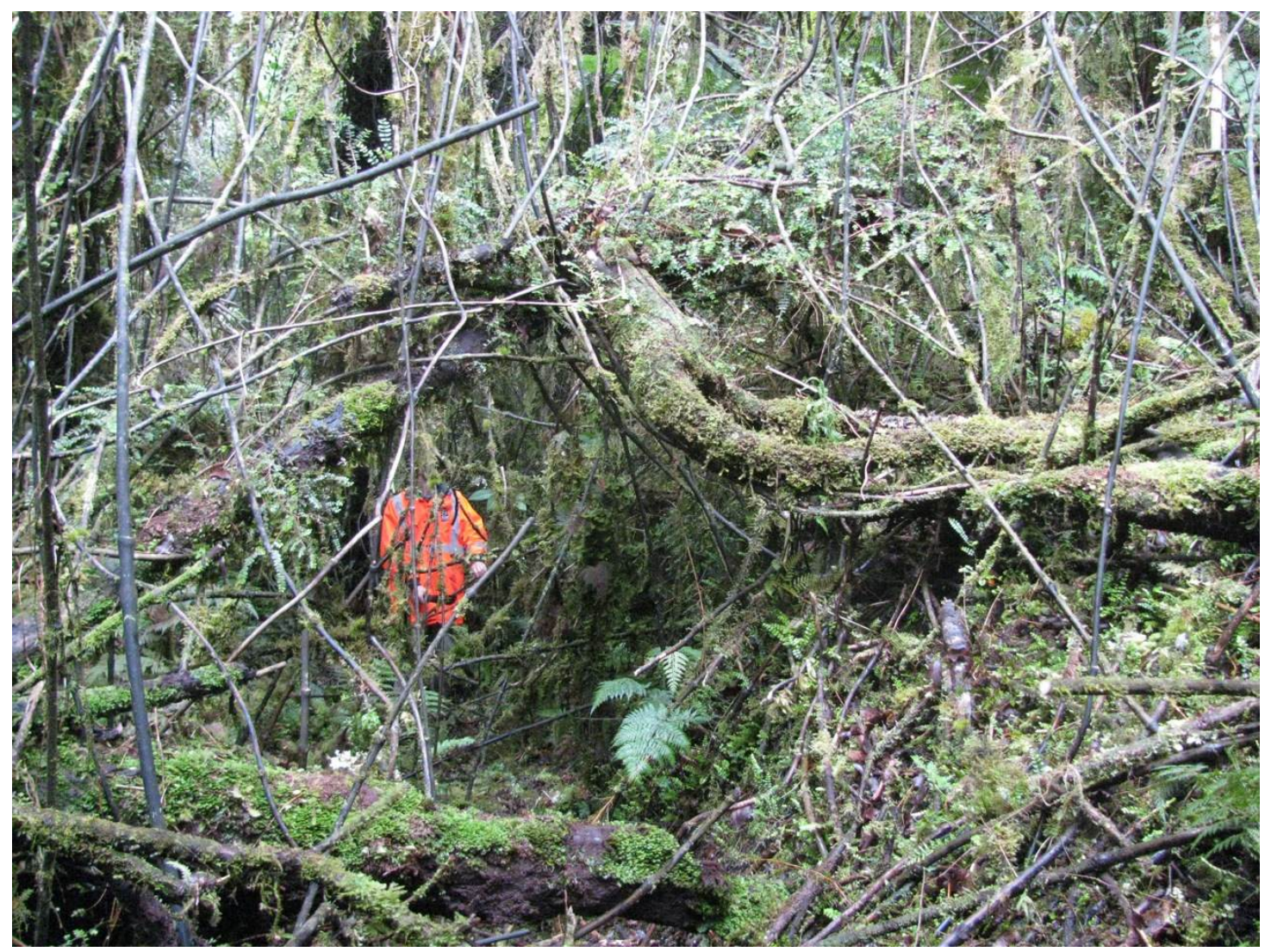

Figure DR6: Field photograph showing the extremely dense rainforest vegetation at the Tartare Creek slip site. Note the geologist in the high-visibility jacket. Wind gap and shutter ridge is located on right of photo in foreground (up to the north). This dense vegetation contributed to a "low" measurement quality designation. 

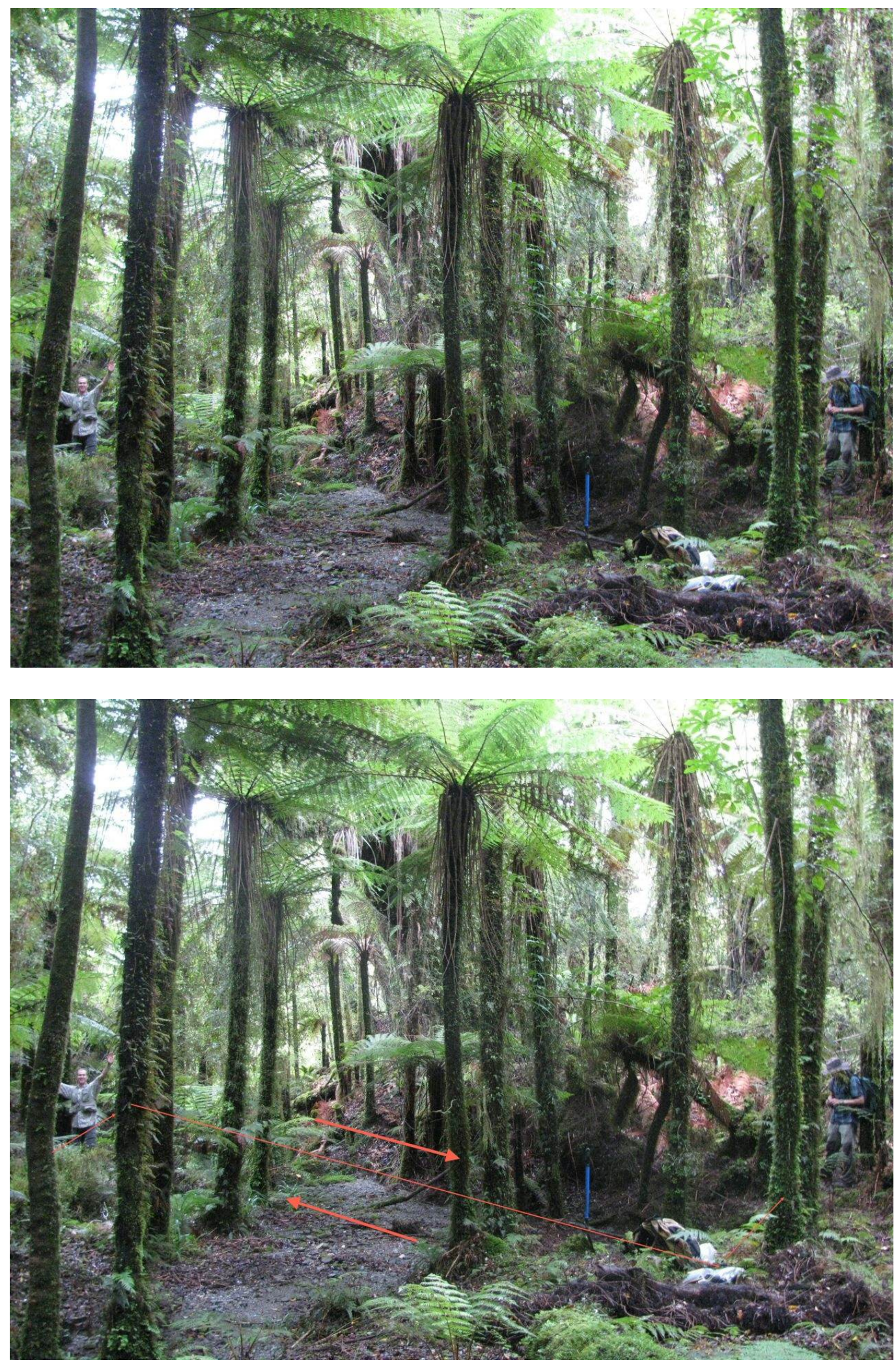

Figure DR7: Photographs showing the wind gap site from south of Gaunt Creek. Note people for scale, with bottom photograph showing the interpreted location of the Alpine Fault with sense of slip. The person on the right is standing on top of the wind gap, which is $13.75 \mathrm{~m} \pm 1.8 \mathrm{~m}$ away from the current creek drainage. Note the rainforest vegetation is quite open compared with the much denser vegetation at Tartare Creek (Fig. 6). Photograph by De Pascale. 
Additionally with the lidar, each site was assigned a qualifier of high, moderate, low, or poor quality, based on the back-slipped data and quality of offset fit following the subjective scales developed by previous workers to rate quality of offset features (e.g. Sieh, 1978). Generally, if extremely dense rainforest vegetation made on-the-ground measurements difficult to obtain, these locations were given low to poor quality designations (e.g. Fig. 6). Low- and poor-ranked data were excluded from slip calculations. Uncertainties were measured in the field and debated by the field teams at each of the field sites. Sites where visibility was good and unhindered by vegetation, and the displacements were low, achieved field estimates of $0.5 \mathrm{~m}$ uncertainty, however with longer, multi-event cumulative displacements, and denser vegetation, the uncertainties were increased accordingly (Table 1). We compiled these slip data and combined them with the offsets documented in the literature to generate the offset distribution for the most recent surface-rupturing events (Fig. 2 main text). Ultimately, some sites provided "higher-resolution" slip data in the field (the channel margin sites from south of Gaunt Creek), whereas other sites with very dense vegetation (e.g. McCulloughs Creek) were extremely difficult to measure in the field, in particular with longer offsets, making the lidar data more reliable. By combining the data, we were able to best evaluate dextral slip along the fault in these challenging field conditions.

I report a central preferred measurement and minimum and maximum measurements (Tables $1 \&$ 2) reflecting measurement uncertainties (e.g. McGill and Sieh, 1991). These sites were then back-slipped (e.g. Frankel et al., 1997; Zielke et al., 2010, 2012) in order to check the preferred offset amounts (Fig. 1). South of Gaunt Creek near the wind gap sites where progressive displacement is apparent (Fig. 1), a 
combined uncertainty of $\pm 1 \mathrm{~m}$ for the shortest dextral strike-slip displacements was determined based on field measurements.

Finally, measured dextral offsets (including uncertainties) were divided by the central Alpine Fault dextral slip-rate $(27 \pm 5 \mathrm{~mm} / \mathrm{yr}$; Norris and Cooper, 2001) to explore the timing of past Alpine Fault surface ruptures, assuming steady interseismic strain accumulation that is accommodated primarily by slip in large earthquakes (Wallace et al., 2007; Boese et al., 2012).

\section{SITE DESCRIPTIONS}

Slip sites located along the fault in the lidar and on the ground were, from south to north the Tartare Creek, South of Gaunt Creek (or Wind Gap/Slip Creek sites - informal names), Wee Creek (informal name), and McCulloughs Creek (Fig. 1). Each of these sites is addressed in detail below.

The sites south of Gaunt Creek are located $\sim 1 \mathrm{~km}$ south of Gaunt Creek immediately south of the first major creek (unnamed; we propose the informal name "Slip Creek" here because of the important slip records adjacent to this creek) south of Gaunt Creek (Table 1; Figs. $1 \& 10$ ). These sites were located based on the prominent offset channel riser that corresponds with a shutter ridge. Along an approximately $200 \mathrm{~m}$ along-strike section of the fault, a wind gap, an offset channel margin along the shutter ridge and two channel margins are all clearly dextrally offset. The main trace of the Alpine Fault is apparent as a northeast-striking linear valley and a sag pond is located on the fault where the shutter ridge ponds alluvium. This sag pond was discovered during fieldwork (Fig. 8), has standing water present, and composed of very fine-grained clay and slit with abundant organics, and likely 
contains stratigraphic records that could be tied with the offset measurements here for local Alpine Fault slip-rate estimates and should be targeted for future research.

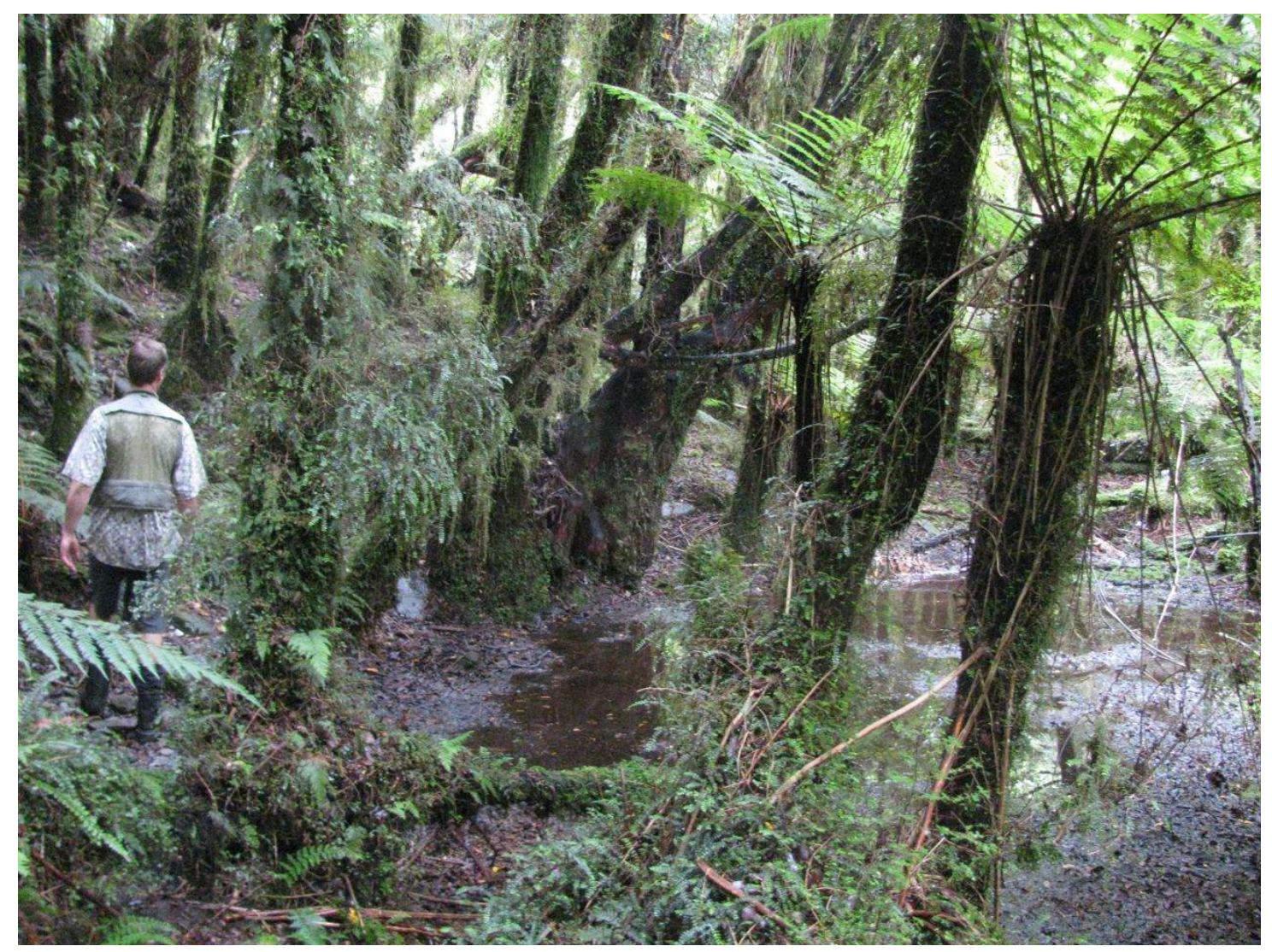

Figure DR8: Field photograph looking northeast along the Alpine Fault showing a sag pond near the wind gap sites. This site should be targeted for dating (photograph by De Pascale).

At the southern end of this site, the linear valley along the fault is being eroded with springs coming out of the sidewall of the modern terrace riser at the fault zone. The wind gap, which is correlated with a small channel having similar channel architecture on the hanging wall of the fault, is quite clear in the lidar data and on the ground. It appears that during the past two earthquakes the shutter ridge and uphill facing scarp (through uplift along a minor frontal thrust here) deflected the drainage (leaving an abandoned channel/wind gap) south along the fault where it previously flowed through the gap (Figs. $1 \& 8$ ). Northeast of the wind gap, the true left flank of a channel margin intersects a shutter ridge that has been offset and clearly visible in 
the lidar and in the field. Northeast of the shutter ridge are two channel margins that appear to have only been offset once, based on their short distance, whereas the wind gap was likely offset by two events, and the shutter ridge likely offset by three events. The channel margins are inherently younger features that likely formed between the penultimate event and the 1717 earthquake, and were then offset during the 1717 earthquake. This relationship is clear when back-slipping the sites as the "young" channel margins (post-penultimate and offset in 1717), and younger active features to the north no longer correlate after backslipping to before the penultimate event because they had not yet formed in the paleo-drainage (Fig. 1).

The Tartare Creek site (Table 1; Figs. $3 \&$ 6) is located $\sim 300$ m northeast of where the Tartare Creek exits the Southern Alps. The site has a number of prominent strike-slip features that helped us locate it including a channel margin (the true left side of the channel) that drains the rangefront and is deflected where it crosses the main trace of the fault. Immediately northeast of here there is a major drainage that is deflected by $\sim 30 \mathrm{~m}$ (Fig. 3A), and a beheaded channel on the footwall of the fault. The Alpine Fault is clearly visible as a northeast-striking linear valley where the channel intersects a shutter ridge. The creek was deflected dextrally in the past two earthquakes at this site with current drainage sub-parallel to the fault trace along the shutter ridge (Fig. 3). In the past two earthquakes along the fault, dextral movement of the shutter ridge left the channel margin behind as a wind gap. In the field, this site was very difficult to locate and has an extremely dense rainforest vegetation cover. However GPS and lidar maps helped locate the site and determine the relationships between the channel margins and the wind gap, and measure the dextral offset there, although visibility on the ground was limited (Fig. 6). 
The McCulloughs Creek site is located north of the Whataroa River at the junction of McCulloughs Creek (a tributary of the Whataroa River) and the Alpine Fault (Table 1; Fig. 4). At the site, a flight of terraces on the footwall of the fault is dextrally displaced along the main strike-slip strand of the fault. The main trace of the fault is visible as a northeast-striking linear valley located northeast of the McCulloughs Creek. In the field, visibility was limited due to extremely dense vegetation and this yielded "poor" slip measurement data, whereas with the lidar data, we were able to back-slip the channel margins and terrace treads into an acceptable locations. Note that this site clearly demonstrates diachroneity of terrace abandonment, i.e. flights of small terraces that progressively step down from the back to the front of a tread, because portions of the lower tread lie within sheltered corners which are thus transported away from the active channel during strike-slip faulting (as first identified by Cowgill, 2007). Because this site exceeded three events and is at the upper end of this $<30 \mathrm{~m}$ offset dataset, it is difficult to determine the number of possible surface ruptures at this site although we infer 4-6 major earthquakes based on uncertainties in the measurements and associated slip-per-event at this location. Although no samples were found to date these terraces, future fieldwork there may yield results that can help determine dextral slip-rates along the fault at this site.

The Wee Creek site immediately south of McCulloughs was found in the field under extremely dense vegetation that did not allow it to be visualized in the lidar (Table 1; Fig. 9). At this location, an active creek, unnamed and referred to as "Wee Creek", is dextrally offset by $\sim 7-8 \mathrm{~m}$. Because the channel is active, margins were being actively eroded, and the absence of this site in the lidar, this site was given a low quality designation. 


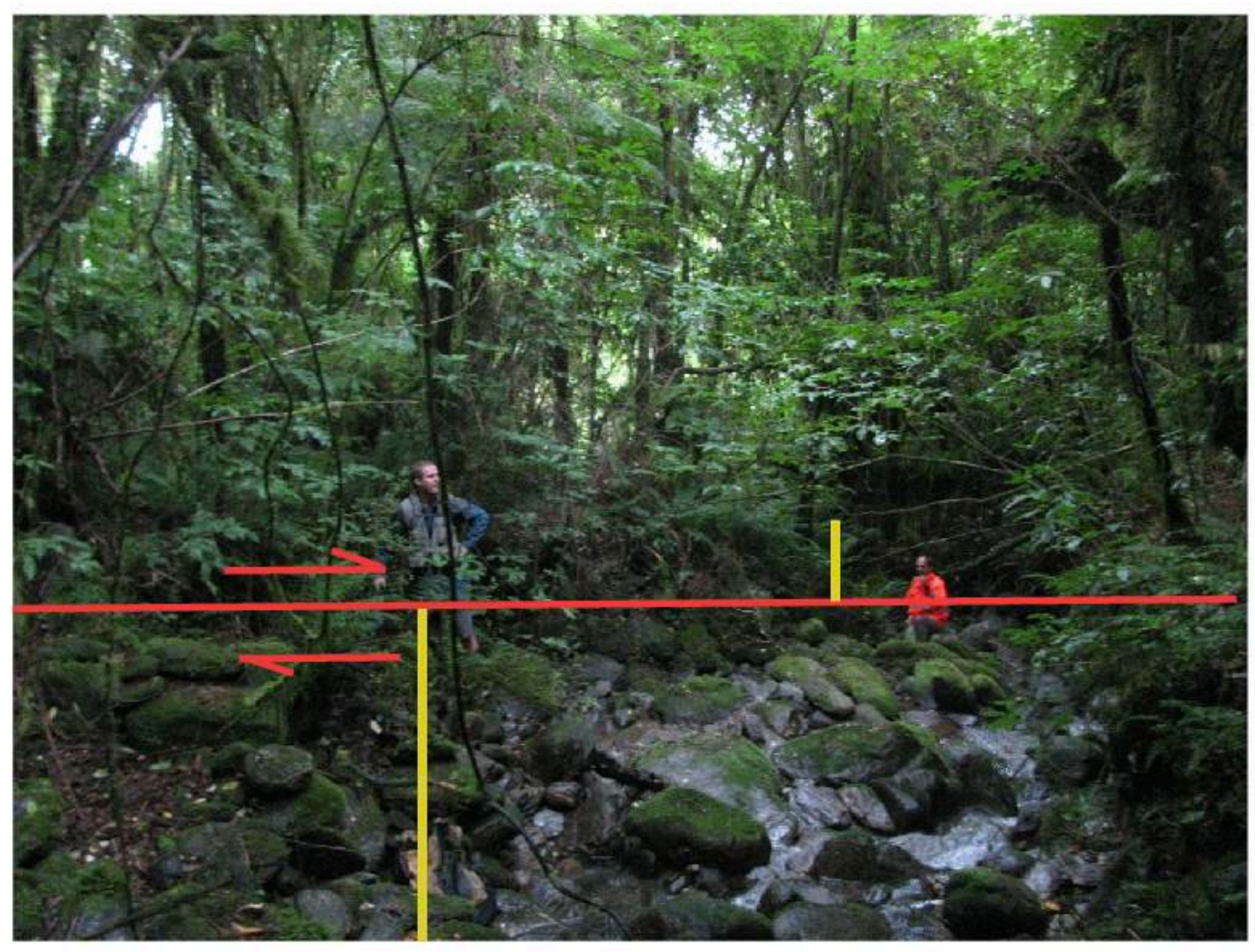

Figure DR9: Field photograph looking downstream showing the dextral offset of the channel margin at "Wee Creek". Alpine Fault shown in red (photograph by De Pascale).

\section{DATA COMPILATION}

Our tabulated data from the offset sites from both the field and the lidar can be found below in Tables DR1 \& DR2. 
De Pascale et al., 2014; Alpine Fault Supplemental Information

\begin{tabular}{|c|c|c|c|c|c|c|c|c|}
\hline \multicolumn{9}{|c|}{ Table DR1: OVERVIEW OF FIELD AND LIDAR OFFSET MEASURMENTS FROM THE CENTRAL ALPINE FAULT } \\
\hline $\begin{array}{l}\text { Feature } \\
\text { number }\end{array}$ & Site & $\begin{array}{c}\text { Lidar or } \\
\text { field data }\end{array}$ & Landform & $\begin{array}{c}\text { Distance } \\
\text { north of } \\
\text { Franz J. } \\
(\mathbf{k m})\end{array}$ & $\begin{array}{l}\text { Location } \\
\text { (Lat/Long) }\end{array}$ & $\begin{array}{c}\text { Preferred } \\
\text { dextral } \\
\text { offset with } \\
\text { uncertainty } \\
\text { (m) }\end{array}$ & Quality & $\begin{array}{l}\text { Preferred } \\
\text { value at site } \\
\text { based on } \\
\text { quality and } \\
\text { uncertainty } \\
\text { (m) }\end{array}$ \\
\hline 1 & Tartare Creek & lidar & \begin{tabular}{|c|}
$\begin{array}{c}\text { true left of channel } \\
\text { margin }\end{array}$ \\
\end{tabular} & 2 & \begin{tabular}{|c|}
$43^{\circ} 22^{\prime} 47.06 \mathrm{~S}$ \\
$170^{\circ} 11^{\prime} 59.35^{\prime \prime} \mathrm{E}$ \\
\end{tabular} & $12 \pm 2$ & Med & \multirow{2}{*}{$12 \pm 2$} \\
\hline 1 & Tartare Creek & field & $\begin{array}{c}\text { true left of channel } \\
\text { margin }\end{array}$ & 2 & \begin{tabular}{|c|}
$43^{\circ} 22^{\prime} 47.06 \mathrm{~S}$ \\
$170^{\circ} 11^{\prime} 59.35^{\prime \prime} \mathrm{E}$ \\
\end{tabular} & $10 \pm 2$ & Low & \\
\hline 2 & $\begin{array}{l}\text { Wind Gap } \\
\text { south of GC }\end{array}$ & lidar & $\begin{array}{c}\text { wind gap visable in } \\
\text { the lidar south of } \\
\text { GC, from channel } \\
\text { exiting SW along } \\
\text { shutter ridge }\end{array}$ & 13 & $\begin{array}{c}43^{\circ} 19^{\prime} 19.28^{\prime \prime S} \\
170^{\circ} 18^{\prime} 35.57^{\prime \prime} \mathrm{E}\end{array}$ & $14 \pm 2$ & High & \multirow{2}{*}{$13.75 \pm 1.8$} \\
\hline 2 & $\begin{array}{l}\text { Wind Gap } \\
\text { south of GC }\end{array}$ & field & $\begin{array}{c}\text { wind gap visable in } \\
\text { the lidar south of } \\
\text { GC, from channel } \\
\text { exiting SW along } \\
\text { shutter ridge }\end{array}$ & 13 & $\begin{array}{c}43^{\circ} 19^{\prime} 19.28^{\prime \prime S} \\
170^{\circ} 18^{\prime} 35.57^{\prime \prime} \mathrm{E}\end{array}$ & $13.5 \pm 1.5$ & High & \\
\hline 3 & $\begin{array}{c}\text { Shutter Ridge } \\
\text { Margin }\end{array}$ & lidar & $\begin{array}{c}\text { true left of fluvial } \\
\text { terrace and visable } \\
\text { in the lidar }\end{array}$ & 13 & $\begin{array}{c}43^{\circ} 19^{\prime} 19.28^{\prime \prime S} \\
170^{\circ} 18^{\prime} 35.57^{\prime \prime} \mathrm{E}\end{array}$ & $23 \pm 2$ & High & \multirow{2}{*}{$22 \pm 2.7$} \\
\hline 3 & $\begin{array}{c}\text { Shutter Ridge } \\
\text { Margin }\end{array}$ & field & $\begin{array}{l}\text { true left of fluvial } \\
\text { terrace and visable } \\
\text { in the lidar }\end{array}$ & 13 & $\begin{array}{c}43^{\circ} 19^{\prime} 19.28^{\prime \prime S} \\
170^{\circ} 18^{\prime} 35.57^{\prime \prime} \mathrm{E}\end{array}$ & $21 \pm 3$ & Med & \\
\hline 4 & South of GC & lidar & $\begin{array}{c}\text { true left of fluvial } \\
\text { terrace (channel } \\
\text { margin) in contact } \\
\text { with site above) }\end{array}$ & 13 & $\begin{array}{c}43^{\circ} 19^{\prime} 19.28^{\prime \prime S} \\
170^{\circ} 18^{\prime} 35.57^{\prime \prime} \mathrm{E}\end{array}$ & $7.5 \pm 2$ & High & \multirow{2}{*}{$7 \pm 0.5$} \\
\hline 4 & South of GC & field & $\begin{array}{c}\text { true left of fluvial } \\
\text { terrace (channel } \\
\text { margin) in contact } \\
\text { with site above) }\end{array}$ & 13 & $\begin{array}{c}43^{\circ} 19^{\prime} 19.28^{\prime \prime S} \\
170^{\circ} 18^{\prime} 35.57^{\prime \prime} \mathrm{E}\end{array}$ & $7 \pm 0.5$ & High & \\
\hline 5 & South of GC & lidar & $\begin{array}{c}\text { true left of fluvial } \\
\text { terrace (eastern } \\
\text { most at site) }\end{array}$ & 13 & $\begin{array}{c}43^{\circ} 19^{\prime} 19.28^{\prime \prime} \mathrm{S} \\
170^{\circ} 18^{\prime} 35.57^{\prime \prime} \mathrm{E}\end{array}$ & $7.5 \pm 2$ & High & \multirow{2}{*}{$8 \pm 0.5$} \\
\hline 5 & South of GC & field & $\begin{array}{c}\text { true left of fluvial } \\
\text { terrace } \\
\text { (easternmost at } \\
\text { site) }\end{array}$ & 13 & $\begin{array}{c}43^{\circ} 19^{\prime} 19.28^{\prime \prime S} \\
170^{\circ} 18^{\prime} 35.57^{\prime \prime} \mathrm{E}\end{array}$ & $8 \pm 0.5$ & High & \\
\hline 6 & $\begin{array}{c}\text { Wee Creek } \\
\text { (near } \\
\text { McCulloughs) }\end{array}$ & $\begin{array}{l}\text { field (not } \\
\text { visable in } \\
\text { lidar) }\end{array}$ & $\begin{array}{l}\text { true right creek } \\
\text { channel margin }\end{array}$ & 24 & $\begin{array}{c}43^{\circ} 15^{\prime} 55.19^{\prime \prime} \mathrm{S} \\
170^{\circ} 25^{\prime} 15.34 " \mathrm{E}\end{array}$ & $7.2 \pm 1$ & Low & \multirow{2}{*}{$7.7 \pm 1.1$} \\
\hline 6 & $\begin{array}{c}\text { Wee Creek } \\
\text { (near } \\
\text { McCulloughs) }\end{array}$ & $\begin{array}{l}\text { field (not } \\
\text { visable in } \\
\text { lidar) }\end{array}$ & $\begin{array}{l}\text { true left creek } \\
\text { channel margin }\end{array}$ & 24 & $\begin{array}{c}43^{\circ} 15^{\prime} 55.19^{\prime \prime} \mathrm{S} \\
170^{\circ} 25^{\prime} 15.34^{\prime \prime} \mathrm{E}\end{array}$ & $8.2 \pm 1$ & Low & \\
\hline 7 & $\begin{array}{c}\text { McCulloughs } \\
\text { Creek }\end{array}$ & lidar & $\begin{array}{c}\text { left edge of terrace } \\
\text { riser of MC }\end{array}$ & 25 & $\begin{array}{c}43^{\circ} 15^{\prime} 47.30^{\prime \prime S} \\
170^{\circ} 25^{\prime} 35.46^{\prime \prime} \mathrm{E}\end{array}$ & $33 \pm 3$ & Med & \multirow{2}{*}{$33 \pm 3$} \\
\hline 7 & $\begin{array}{c}\text { McCulloughs } \\
\text { Creek }\end{array}$ & field & $\begin{array}{l}\text { left edge of terrace } \\
\text { riser north of MC }\end{array}$ & 25 & \begin{tabular}{|c|}
$43^{\circ} 15^{\prime} 47.30^{\prime \prime S}$ \\
$170^{\circ} 25^{\prime} 35.46^{\prime \prime} \mathrm{E}$
\end{tabular} & $26 \pm 10$ & Poor & \\
\hline
\end{tabular}




\begin{tabular}{|c|c|c|c|}
\hline Mean Values & $\begin{array}{l}\frac{\text { Central }}{\text { dextral slip }} \\
\frac{\text { with }}{\text { uncertainty }} \\
\text { (m) }\end{array}$ & $\frac{\text { Inferred number }}{\underline{\text { of events }}}$ & $\begin{array}{c}\frac{\frac{\text { Mean }}{\text { single }}}{\text { event }} \\
\frac{\text { displacem }}{\text { ent (m) }} \\
\end{array}$ \\
\hline $\begin{array}{c}\text { mean combined } \\
1717 \text { without } \\
\text { poor or low } \\
(\mathrm{n}=4)\end{array}$ & $7.5 \pm 1$ & 1 & 7.5 \\
\hline $\begin{array}{l}\text { Mean combined } \\
\text { two events } \\
\text { without poor or } \\
\text { low }(\mathrm{n}=3)\end{array}$ & $13.2 \pm 2$ & 2 & 6.6 \\
\hline $\begin{array}{l}\text { Mean three } \\
\text { events without } \\
\text { poor or low } \\
(\mathrm{n}=1)\end{array}$ & $22 \pm 2.7$ & 3 & 7.3 \\
\hline
\end{tabular}

Table DR2: Combined values from both lidar and field measurements including inferred number of events and the mean single event displacement estimates. 
Table DR3: COMPILATION OF EARTHQUAKE TIMING RECORDS FROM PALEOSEISMIC DATA IN WESTLAND DURING THE PAST 1.1 Ka

\begin{tabular}{|c|c|c|c|c|c|c|c|c|c|c|c|}
\hline $\begin{array}{c}\text { Event year } \\
\text { (Mean calendar } \\
\text { year with } \\
\text { uncertainity) }\end{array}$ & This Study & $\begin{array}{c}\text { Berryman et } \\
\text { al., 2012a }\end{array}$ & $\begin{array}{c}\text { Berryman et } \\
\text { al., 2012b }\end{array}$ & $\begin{array}{c}\text { Howarth et } \\
\text { al. } 2012\end{array}$ & $\begin{array}{c}\text { Reznichenko } \\
\text { et al., } 2012\end{array}$ & $\begin{array}{l}\text { Wells and } \\
\text { Goff, 2007 } \\
\text { (trees on } \\
\text { dunes) }\end{array}$ & $\begin{array}{c}\text { Wells et al., } \\
1999 \text { (tree } \\
\text { cohorts) }\end{array}$ & $\begin{array}{c}\text { Yetton } \\
1998 \\
\text { (trench) }\end{array}$ & $\begin{array}{c}\text { Bull 1996 } \\
\text { (lichens on } \\
\text { rockfalls) }\end{array}$ & $\begin{array}{c}\text { Adams } \\
1980 \\
\text { (terrace } \\
\text { ages) }\end{array}$ & $\begin{array}{l}\text { Central Alpine } \\
\text { fault event? } \\
\text { (yes or no) }\end{array}$ \\
\hline 1717 & SED & 1770 to 1400 & N.D. & 1717 & 1740 to 1680 & 1740 to 1690 & 1740 to 1700 & $\begin{array}{c}1750 \text { to } \\
1650\end{array}$ & 1750 to 1740 & N.D. & Yes \\
\hline $1440( \pm 50 \mathrm{yr})$ & 1495 to 1365 & N.D. & N.D. & 1410 to 1370 & 1450 to 1360 & 1490 to 1440 & 1500 to 1440 & $\begin{array}{c}1450 \text { to } \\
1400\end{array}$ & 1490 to 1480 & 1430 & Yes \\
\hline $1210( \pm 90 \mathrm{yr})$ & 1290 to 1070 & 1370 to 1210 & N.D. & 1120 to 1060 & 1270 to 1160 & 1290 to 1240 & N.D. & N.D. & 1230 to 1220 & N.D. & Yes \\
\hline
\end{tabular}

Notes: Earthquakes rounded to nearest decade pre-1717 with mean date based on mean of all reported values. (N.D.) is not detected. (+) evidence for post-earthquake lake sediment deposition only in the absence of turbidites, while $(*)$ represents a megaturbidite (strong shaking) without post-seismic sediment pulse. Shaded areas are Central Alpine fault earthquakes with $\sim 7 \mathrm{~m}$ slip. The 1600 earthquake may not have had a surface rutpure (>Mw6.5) or had a surface rupture along the Northern AF long. SED represents the single event displacments we measured from the 1717 event in this study. The 1826 is now assumed to be from a subduction earthquake south of the Alpine Fault due to widespread tsunami deposits (Figure 3.1). (^) suggests that the earthqauke around 1600 was along the northern and central AF, but did not contribute much to the slip at the sites we visted in the field, although this is clear in sites further

Table DR3: Compilation of all recent evidence from the literature on the timing of earthquakes for the past $\sim 1.1$ ka in Westland New Zealand along the Alpine Fault. Alpine Fault earthquakes in 1717, ca. 1440, ca. 1210, and ca. 930. Note that the "This Study" age of 1060 to 840 is an estimate based on a back projection of the mean slip measured in this study and assuming constant long-term slip rate (after Norris and Cooper, 
Finally, we conducted a one on one comparison of the paleoseismic record and our offset measurements in order to see if indeed uniform slip is possible here (Table 4).

Table DR4. COMPARISON OF SLIP WITH SLIP RATE, CENTRAL ALPINE FAULT

\begin{tabular}{|c|c|c|c|}
\hline Model 1 & & & \\
\hline $\begin{array}{c}\text { EQ date } \\
\text { (calendar year) }\end{array}$ & $\begin{array}{l}\text { Slip per event at } \\
\text { sites }(\mathrm{m})\end{array}$ & $\begin{array}{l}\text { Required slip-rate since } \\
\text { last earthquake to generate } \\
\text { dextral slip-per-event } \\
\text { (range in } \mathrm{mm} / \mathrm{yr} \text { ) } \\
\end{array}$ & $\begin{array}{l}\text { Mean slip rate } \\
\text { required (mm/yr) }\end{array}$ \\
\hline 1717 & $5-9.3$ & 43 to 79 & 61 \\
\hline 1600 & $5-9.3$ & 29 to 54 & 42 \\
\hline 1440 & $5-9.3$ & 24 to 44 & 34 \\
\hline 1210 & $5-9.3$ & 17 to 32 & 25 \\
\hline 930 & $5-9.3$ & n.a. & N.D. \\
\hline \multicolumn{4}{|l|}{ Model 2} \\
\hline $\begin{array}{c}\text { EQ date } \\
\text { (calendar year) }\end{array}$ & $\begin{array}{l}\text { Slip per event at } \\
\text { sites }(\mathrm{m})\end{array}$ & $\begin{array}{l}\text { Required slip-rate since } \\
\text { last earthquake to generate } \\
\text { dextral slip-per-event } \\
\text { (range in } \mathrm{mm} / \mathrm{yr} \text { ) } \\
\end{array}$ & $\begin{array}{l}\text { Mean slip rate } \\
\text { required }(\mathrm{mm} / \mathrm{yr})\end{array}$ \\
\hline 1717 & 5 to 9.3 & 18 to 34 & 26 \\
\hline 1440 & 5 to 9.3 & 22 to 40 & 31 \\
\hline 1210 & 5 to 9.3 & 17 to 32 & 25 \\
\hline 930 & 5 to 9.3 & n.a. & N.D. \\
\hline
\end{tabular}

Table DR4: Two potential models that compare our offset measurements with the Alpine Fault slip rate required to achieve this amount of surface slip between events. Note that in Model 1, which includes the 1600 event, that the slip-rate would have to exceed the entire plate deformation at this location $(>40 \mathrm{~mm} / \mathrm{yr})$ in order to generate 5 to $9.3 \mathrm{~m}$ of slip per event if every earthquake has $\sim 7 \mathrm{~m}$ of dextral slip. Model 2 is perhaps more realistic based on the mean slip-rate required based on these earthquake ages. This suggests that the Alpine Fault earthquake record here is dominated by large $\sim 7 \mathrm{~m}$ dextral surface ruptures, with moderate-large earthquakes in between these major surface ruptures (e.g. 1600 earthquake) consistent with bimodal behavior which is perhaps rupture width limited. 
In the first model (Table 4) we apply the slip per event to the intervals between earthquakes at $1717,1600,1440,1210$, and 930 to calculate the slip rates required to generate these offsets (e.g. the interval between 1717 and 1600 is 117 years and to obtain 5-9.3 m of offset during this period would require a slip rate of 43-79 mm/yr). In the second model, we remove the 1600 event to test if perhaps this event was along another fault (and thus the off-fault records are not from along the Alpine Fault).

Clearly these high slip rates suggest that our two explanations, i.e. bimodal behaviour, or that some of the shaking records are from other seismic sources, are important observations.

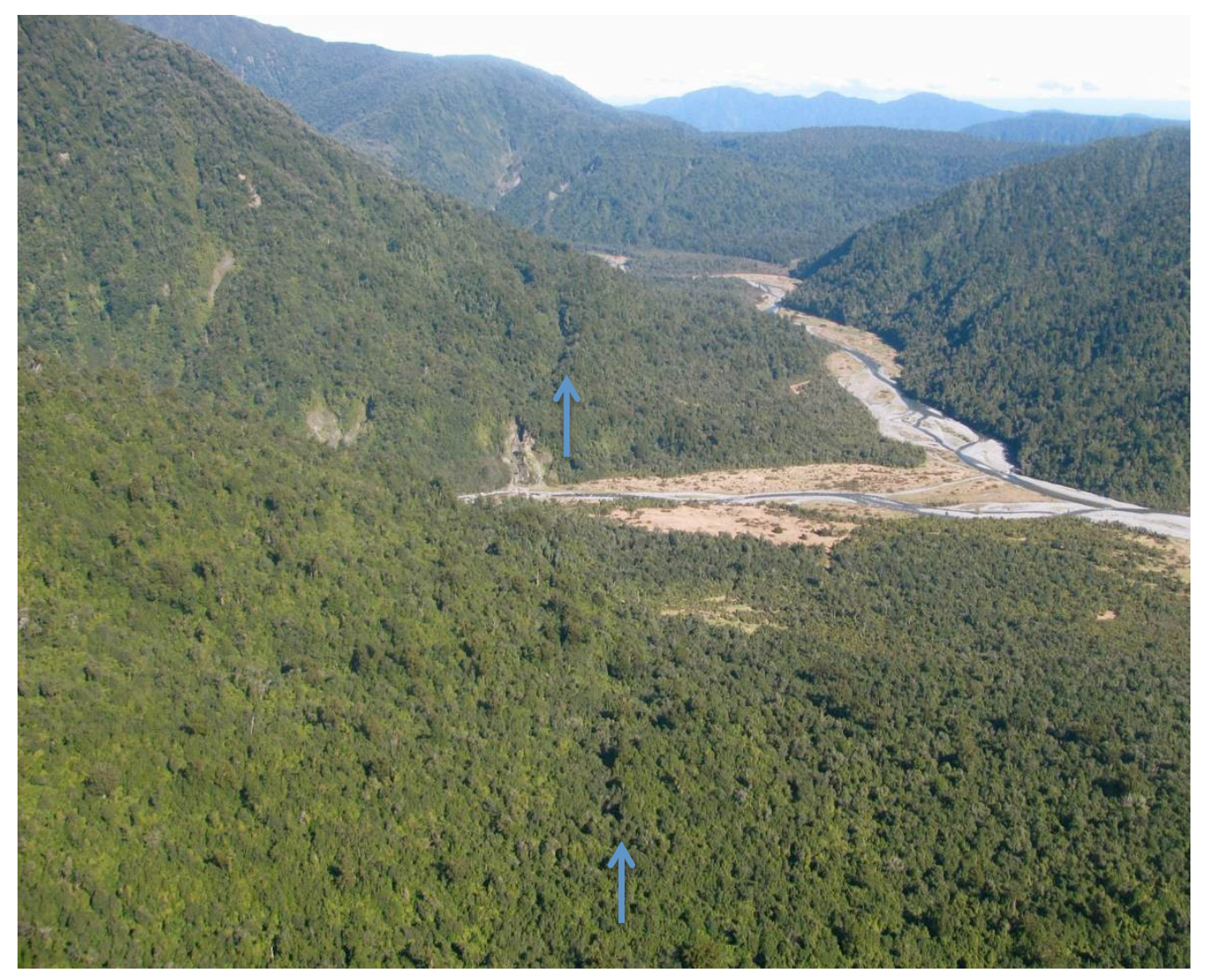

Figure DR10. Oblique photograph above the Waitangitaona River looking southwest along the Alpine Fault above the shutter ridge and wind gap sites. Note the dense rainforest cover and surface rupture trace of the Alpine Fault (shown with arrows) trending across topography. Darnley Creek flows left to right through this photograph into the Waitangitaona River (photograph by De Pascale). 


\section{REFERENCES CITED}

Adams, J., 1980, Paleoseismicity of the Alpine fault seismic gap, New Zealand: Geology, v. 8, p. 72-76, doi:10.1130/0091-7613(1980)8<72:POTAFS >2.0.CO;2.

Berryman, K.R., 1975, Earth Deformation Studies Reconnaissance of the Alpine Fault, Immediate Report, Earth Deformation Section E.D.S. No. 30a \& 30b: Wellington, New Zealand Geological Survey, Department of Scientific and Industrial Research, Lower Hutt, New Zealand. 26 p.

Berryman, K., Cooper, A., Norris, N., Villamor, P., Sutherland, R., Wright, T., Schermer, E., Langridge, R., and Baisi, G., 2012, Late Holocene rupture history of the Alpine fault in South Westland, New Zealand: Bulletin of the Seismological Society of America, v. 102, p. 620-638, doi:10.1785/0120110177.

Berryman, K.R., Cochran, U.A., Clark, K.J., Biasi, G.P., Langridge, R.M., and Villamor, P., 2012, Twenty-four surface-rupturing earthquakes over 8000 years on the Alpine fault, New Zealand: Science, v. 336, no. 6089, p. 1690-1693, doi:10.1126/science.1218959.

Boese, C.M., Townend, J., Smith, E., and Stern, T., 2012, Microseismicity and stress in the vicinity of the Alpine Fault, central Southern Alps, New Zealand: Journal of Geophysical Research, v. 117, B02302, doi:10.1029/2011JB008460.

Bull, W.B., 1996, Prehistorical earthquakes on the Alpine fault, New Zealand: Journal of Geophysical Research, v. 101, no. B3, p. 6037-6050, doi:10.1029/95JB03062.

Cowgill, E., 2007, Impact of riser reconstructions on estimation of secular variation in rates of strike-slip faulting: Revisiting the Cherchen River site along the Altyn Tagh Fault, NW China: Earth and Planetary Science Letters, v. 254, p. 239-255, doi:10.1016/j.epsl.2006.09.015.

De Pascale, G.P. 2014, Neotectonics and Paleoseismology of the Central Alpine Fault, New Zealand, PhD Thesis, University of Canterbury, Christchurch, New Zealand, 238 p.

De Pascale, G.P., and Langridge, R.M., 2012, New on-fault evidence for a great earthquake in A.D. 1717, central Alpine fault, New Zealand: Geology, v. 40, p. 791-794, doi:10.1130/G33363.1.

Frankel, K.L., Dolan, J.F., Finkel, R.C., Own, L.A., and Hoeft, J.S., 1997, Spatial variations in slip rate along the Death Valley-Fish Lake Valley fault system determined from LiDAR topographic data and cosmogenic 10Be geochronology: Geophysical Research Letters, v. 34, doi:10.1029/2007GL030549.

Grant Ludwig, L., Akçiz, S.O., Noriega, G.R., Zielke, O., and Arrowsmith, J.R., 2010, Climatemodulated channel incision and rupture history of the San Andreas Fault in the Carrizo Plain: Science, v. 327, p. 1117-1119, doi:10.1126/science.1182837.

Griffiths, G.A., and McSaveney, M.J., 1983, Distribution of mean annual precipitation across some steepland regions of New Zealand: New Zealand Journal of Science, v. 26, n. 2, p. 197- 209. 
Howarth, J.D., Fitzsimmons, S.J., Norris, R.J., and Jacobsen, G.E., 2012, Lake sediments record cycles of sediment flux driven by large earthquakes on the Alpine fault, New Zealand: Geology, v. 40, p. 1091-1094, doi:10.1130/G33486.1.

Langridge, R.M., Villamor, P., Basili, R., Almond, P., Martinez-Diaz, J.J., and Canora, C., 2010, Revised slip rates for the Alpine fault at Inchbonnie: Implications for plate boundary kinematics of South Island, New Zealand: Lithosphere, v. 2, p. 139-152, doi:10.1130/L88.1.

Langridge, R.M., Ries, W.F., Farrier, T., Barth, N.C., Khajavi, and De Pascale, G.P., 2013. Developing sub 5-m lidar DEMs for forested sections of the Alpine and Hope faults, South Island New Zealand: Implications for structural interpretations: Journal of Structural Geology, doi.org/10.1016/ j.jsg.2013.11.007

McGill, S.F., and Sieh, K.E., 1991, Surfical offsets on the Central and Eastern Garlock Fault associated with prehistoric earthquakes: Journal of Geophysical Research, v. 96, no. B13, p. 21597-21621, doi:10.1029/91JB02030.

Norris, R.J., and Cooper, A.F., 2001, Late Quaternary slip rates and slip partitioning on the Alpine fault, New Zealand: Journal of Structural Geology, v. 23, p. 507-520, doi:10.1016/S0191-8141(00)00122-X.

Reznichenko, N.V., Davies, T.R.H., Shulmeister, J., and Larson, S.H., 2012, A new technique for identifying rock avalanche-sourced sediment in moraines and some paleoclimatic implications: Geology, v. 40, no. 4, p. 319-322, doi:10.1130/G32684.1.

Salisbury, J.B., Rockwell, T.K., Middleton, T.J., and Hudnut, K.W., 2012, LiDAR and Field Observations of Slip Distribution for the Most Recent Surface Ruptures along the Central San Jacinto Fault Bulletin of the Seismological Society of America April 2012 102:598-619; doi:10.1785/0120110068.

Sieh, K.E., 1978, Slip along the San Andreas Fault associated with the great 1857 earthquake: Bulletin of the Seismological Society of America, v. 68, no. 5, p. 1421-1448.

Sutherland, R., and Norris, R.J., 1995, Late Quaternary displacement rate, paleoseismicity, and geomorphic evolution of the Alpine Fault: Evidence from Hokuri Creek, South Westland, New Zealand: New Zealand Journal of Geology and Geophysics, v. 38, p. 419-430, doi:10.1080 /00288306.1995.9514669.

Wallace, L.M., Beavan, J., McCaffrey, R., Berryman, K., and Denys, P., 2007, Balancing the plate motion budget in the South Island, New Zealand using GPS, geological and seismological data: Geophysical Journal International, v. 168, p. 332-352, doi:10.1111/j.1365-246X.2006.03183.x.

Wallace, R.E., 1968, Notes on stream channels offset by the San Andreas fault, southern Coast Ranges, California, in Dickinson, W.R., and Grantz, A., eds., Prof. of Conf. on Geologic Problems of the San Andreas Fault System: Stanford University, Palo Alto, California, Publication Geological Science, v. 11, p. 6-21.

Wells, A., and Goff, J., 2007, Coastal dunes in Westland, New Zealand, provide a record of paleoseismic activity on the Alpine fault: Geology, v. 35, p. 731-734, doi:10.1130/G23554A.1. 
Wells, A., Yetton, M.D., Duncan, R.P., and Stewart, G.H., 1999, Prehistoric dates of the most recent Alpine fault earthquakes, New Zealand: Geology, v. 27, p.995-998, doi:10.1130/0091- 7613(1999)027<0995:PDOTMR>2.3.CO;2.

Yetton, M.D., 1998, Progress in understanding the paleoseismicity of the central and northern Alpine Fault, Westland, New Zealand: New Zealand Journal of Geology and Geophysics, v. 41, n. 4, p. 475-483.

Zielke, O., Arrowsmith, J.R., Ludwig, L.G., and Akciz, S.O., 2010, Slip in the 1857 and earlier large earthquakes along the Carrizo Plain, San Andreas Fault: Science, v. 327, p. 11191122, doi:10.1126/science.1182781.

Zielke, O., Arrowsmith, J.R., Grant Ludwig, L., and Akciz, S.O., 2012, High res- olution topography-derived offsets along the 1857 Fort Tejon earthquake rupture trace, San Andreas Fault: Bulletin of the Seismological Society of America, v. 102, no. 3, p. 1135-1154, doi:10.1785/0120110230. 